\title{
Microvessel density and VEGF/VEGF receptor status and their role in sarcomas of the pulmonary artery
}

\author{
ANDREAS K.A. GAUMANN ${ }^{1,2}$, GERO SCHERMUTZKI ${ }^{4}$, THOMAS MENTZEL ${ }^{3}$, \\ C. JAMES KIRKPATRICK ${ }^{4}$, JOERG B. KRIEGSMANN ${ }^{5}$ and MORITZ A. KONERDING ${ }^{2}$
}

${ }^{1}$ Institute of Pathology, University of Regensburg, Franz-Josef Strauss Allee 11, D-93042 Regensburg; ${ }^{2}$ Institute of Anatomy, Johannes Gutenberg-Universität Mainz, Becherweg 13-18, D-55099 Mainz; ${ }^{3}$ Institue of Dermatohistopathology, Siemensstr. 6/1, D-88048 Friedrichshafen; ${ }^{4}$ University of Mainz, Langenbeckstr. 1, D-55101 Mainz; ${ }^{5}$ Center of Histopathology, Cytology and Molecular Pathology Trier, Max Planck Str. 18-20, D-54292 Trier, Germany

Received June 25, 2007; Accepted August 22, 2007

\begin{abstract}
Neoangiogenesis, driven by a variety of angiogenic factors, plays an essential role during development and progression of malignant tumors. Vascular endothelial growth factor (VEGF) and its receptors have been designated a central part in the angiogenic process during malignancy. We studied the vascular parameters by means of morphology and morphometry in 7 sarcomas of the pulmonary artery (SPA) and 10 poorly differentiated leiomyosarcomas of soft tissue. Immunohistochemical analysis of VEGF and VEGFR was related to survival and prognosis. The microvessel density (MVD) and intervascular distances (IVD) differed significantly only at sites of necrosis compared to non-necrotic areas in SPA but not for soft tissue leiomyosarcomas. MVD, IVD and vascular surface area (VSA) revealed no difference between SPA and leiomyosarcomas of different origin. We found a more pronounced expression of VEGF in most tumors at sites of necrosis. The receptors were present in a subset of tumor vessels mostly at the tumor border. VEGFR-2 expression was also seen in a subset of tumor cells whereas VEGFR-1 showed only weak expression in some tumors. Local hypoxia seems to induce a higher MVD and a lower IVD at sites of necrosis compared to those areas without necrosis. The presence of necrosis in both sarcoma groups was correlated with the presence of VEGF due to local tumor hypoxia and subsequent up-regulation of VEGFR-2 and VEGFR-1 in tumor vessels as well as tumor cells. Overall and relapse-free survival showed no difference concerning all examined parameters. Thus, microvessel density does not seem to be a prognostic factor in SPA and other sarcomas.
\end{abstract}

Correspondence to: Dr Andreas K.A. Gaumann, Universitätsklinikum Regensburg, Institut für Pathologie, Franz-Josef-Strauss Allee 11, D-93053 Regensburg, Germany

E-mail: andreas.gaumann@klinik.uni-regensburg.de

Key words: angiogenesis, sarcoma, vascular endothelial growth factor, vascular endothelial growth factor receptor, morphometry

\section{Introduction}

Primary sarcomas arising in major blood vessels are very rare. They occur most commonly in the inferior vena cava (1), followed by the pulmonary artery (2) and the aorta. The histological types of these tumors have been described as intimal sarcomas, leiomyosarcomas, malignant fibrous histiocytomas (3) and angiosarcomas (4). Most commonly, these tumors show a rapid clinical progression reflected histologically by high proliferation rates and frequent areas of necrosis. Numerous cases reported in the literature were diagnosed at autopsy. In recent years an increasing number of publications have reported successful surgical treatment of these patients (5). Although adjuvant chemotherapy and/ or radiation were applied most patients died within a few months. It has been shown that up-regulation of drug resistance related proteins occur after chemotherapy, leading to a rapid progression in most cases (6). Thus, the development of new therapeutic strategies, e.g. antiangiogenesis, seems to be of potential interest to possibly improve the clinical outcome of the patients.

Neoangiogenesis plays an important role in certain physiological processes and pathologic conditions as well as solid tumor growth. It is generally accepted that the expansion of tumors beyond a minimum size requires the formation of new blood vessels to supply the tumor tissue with oxygen and nutrients (7). Thus, the inhibition of angiogenesis through antiangiogenic drugs or gene therapy is considered as a promising alternative to conventional tumor therapy (8).

Vascular endothelial growth factor (VEGF) and its receptors Flk-1/KDR (VEGFR-2) and Flt-1 (VEGFR-1) are central regulators of both physiological and pathological angiogenesis $(9,10)$. It is well-known that VEGF and VEGFR-2 are up-regulated in a variety of human tumors, e.g. gliomas and carcinomas (11). The expression of VEGF in tumor cells and VEGFR-2 in the vessel endothelium indicates that this signal transduction system is responsible for the proliferation and survival of tumor vessels. Successful experimental antiangiogenic treatment after application of VEGF neutralizing antibodies (12) or by gene transfer of dominant negative Flk-1 
Table I. Clinical and pathological characteristics of the sarcomas.

\begin{tabular}{|c|c|c|c|c|c|c|c|c|}
\hline $\begin{array}{l}\text { No. of } \\
\text { patient }\end{array}$ & Age & Sex & $\begin{array}{l}\text { Relation to } \\
\text { vessel, size }\end{array}$ & Procedure & $\begin{array}{l}\text { Histology } \\
\text { (grading) }\end{array}$ & Follow-up & $\begin{array}{c}\text { Additional } \\
\text { treatment }\end{array}$ & $\begin{array}{l}\text { Recurrence/ } \\
\text { time after } \\
\text { diagnosis }\end{array}$ \\
\hline 1 & 55 & M & $\begin{array}{l}\text { Pulmonary } \\
\text { trunk } \\
\text { pericardium }\end{array}$ & $\begin{array}{l}\text { PT resection } \\
\text { and } \\
\text { reconstruction }\end{array}$ & $\begin{array}{c}\text { IS } \\
(\mathrm{G} 2)\end{array}$ & $\begin{array}{l}\text { Died } 18 \text { mo } \\
\text { after diagnosis }\end{array}$ & Radiation & $\begin{array}{l}\text { Local }(r) \\
\text { lung }(m) / 7 \text { mo }\end{array}$ \\
\hline 2 & 49 & $\mathrm{~F}$ & $\begin{array}{l}\text { Bifurcation } \\
\text { right PA } \\
\text { branch }\end{array}$ & $\begin{array}{l}\text { Resection PA } \\
\text { replacement }\end{array}$ & $\begin{array}{c}\text { IS } \\
(\mathrm{G} 2)\end{array}$ & $\begin{array}{l}\text { Died } 9 \text { mo } \\
\text { after diagnosis }\end{array}$ & None & Lung $(\mathrm{m}) / 5 \mathrm{mo}$ \\
\hline 3 & 59 & M & $\begin{array}{l}\text { Bifurcation } \\
\text { right PA } \\
\text { branch }\end{array}$ & $\begin{array}{l}\text { Endarterectomy } \\
\text { right pneumo- } \\
\text { nectomy }\end{array}$ & $\begin{array}{c}\text { IS } \\
\text { (G3) }\end{array}$ & $\begin{array}{l}\text { Died } 7 \text { mo } \\
\text { after diagnosis }\end{array}$ & $\begin{array}{l}\text { Radiation } \\
\text { Doxorubicin/ } \\
\text { dacarbacin } \\
5 \text { cycles }\end{array}$ & Local (r)/7 mo \\
\hline 4 & 30 & M & $\begin{array}{l}\text { RV outflow } \\
\text { tract }\end{array}$ & $\begin{array}{l}\text { RV outflow } \\
\text { resection } \\
\text { valve/trunk } \\
\text { reconstruction }\end{array}$ & $\begin{array}{c}\text { IS } \\
(\mathrm{G} 2)\end{array}$ & $\begin{array}{l}\text { Alive } 70 \text { mo } \\
\text { after diagnosis }\end{array}$ & $\begin{array}{l}\text { Adriamycin } \\
5 \text { cycles }\end{array}$ & None \\
\hline 5 & 49 & $\mathrm{~F}$ & $\begin{array}{l}\text { Pulmonary } \\
\text { trunk }\end{array}$ & $\begin{array}{l}\text { Resection } \\
\text { failed }\end{array}$ & $\begin{array}{c}\text { IS } \\
(\mathrm{G} 2)\end{array}$ & $\begin{array}{l}\text { Died } 18 \text { mo } \\
\text { after diagnosis }\end{array}$ & $\begin{array}{l}\text { Adriamycin } \\
6 \text { cycles }\end{array}$ & $\begin{array}{l}\text { Local, lung }(\mathrm{m}) / \\
6 \mathrm{mo}\end{array}$ \\
\hline 6 & 60 & M & $\begin{array}{l}\text { Pulmonary } \\
\text { trunk luminal }\end{array}$ & $\begin{array}{l}\text { Endarterectomy } \\
\text { failed, left } \\
\text { pneumonectomy }\end{array}$ & $\begin{array}{c}\text { IS } \\
\text { (G3) }\end{array}$ & $\begin{array}{l}\text { Alive } 45 \text { mo } \\
\text { after diagnosis }\end{array}$ & $\begin{array}{l}\text { Adriamycin/ } \\
\text { ifosfamid } \\
4 \text { cycles }\end{array}$ & Lung $(\mathrm{m}) / 5 \mathrm{mo}$ \\
\hline 7 & 60 & M & $\begin{array}{l}\text { Pulmonary } \\
\text { trunk }\end{array}$ & $\begin{array}{l}\text { PA resection } \\
\text { luminal }\end{array}$ & $\begin{array}{l}\text { IS recon- } \\
\text { struction }\end{array}$ & $\begin{array}{l}\text { Alive } 31 \text { mo } \\
\text { (G2) after } \\
\text { diagnosis }\end{array}$ & $\begin{array}{l}\text { Adriamycin/ } \\
\text { ifosfamid } \\
4 \text { cycles }\end{array}$ & None \\
\hline 8 & 58 & M & Stomach & Gastrectomy & $\begin{array}{c}\mathrm{LS} \\
(\mathrm{G} 2)\end{array}$ & $\begin{array}{l}\text { Died } 35 \text { mo } \\
\text { after diagnosis }\end{array}$ & None & Liver $(\mathrm{m}) / 25 \mathrm{mo}$ \\
\hline 9 & 72 & $\mathrm{~F}$ & $\begin{array}{l}\text { Gluteal region/ } \\
\text { pelvis }\end{array}$ & Local excision & $\begin{array}{c}\text { LS } \\
(\mathrm{G} 3)\end{array}$ & $\begin{array}{l}\text { Alive } 46 \text { mo } \\
\text { after diagnosis }\end{array}$ & $\begin{array}{l}\text { Radiation } \\
100 \mathrm{~Gy}\end{array}$ & Local (r)/3 mo \\
\hline 10 & 51 & M & $\begin{array}{l}\text { Quadriceps } \\
\text { femoris }\end{array}$ & Local excision & $\begin{array}{c}\text { LS } \\
\text { (G3) }\end{array}$ & $\begin{array}{l}\text { Died } 39 \text { mo } \\
\text { after diagnosis }\end{array}$ & $\begin{array}{l}\text { Adriamycin/ } \\
\text { ifosfamid } \\
10 \text { cycles }\end{array}$ & $\begin{array}{l}\text { Local (r), lung, } \\
\text { pleura, groin } \\
(\mathrm{m}) / 4 \mathrm{mo}\end{array}$ \\
\hline 11 & 61 & M & Bladder & Local excision & $\begin{array}{c}\mathrm{LS} \\
(\mathrm{G} 2)\end{array}$ & $\begin{array}{l}\text { Died } 43 \text { mo } \\
\text { after diagnosis }\end{array}$ & $\begin{array}{l}\text { Etoposid/ } \\
\text { ifosfamid/ } \\
\text { carboplatin/ } \\
2 \text { cycles }\end{array}$ & $\begin{array}{l}\text { Local }(r), \text { liver } \\
\text { liver }(m) / 30 \text { mo }\end{array}$ \\
\hline 12 & 70 & M & Quadriceps & Local excision & $\begin{array}{c}\mathrm{LS} \\
(\mathrm{G} 3)\end{array}$ & $\begin{array}{l}\text { Died } 27 \text { mo } \\
\text { after diagnosis }\end{array}$ & $\begin{array}{l}\text { None }(\mathrm{m}) / \\
21 \mathrm{mo}\end{array}$ & Groin, lung \\
\hline 13 & 48 & M & Calf & Local excision & $\begin{array}{c}\mathrm{LS} \\
(\mathrm{G} 3)\end{array}$ & $\begin{array}{l}\text { Alive } 21 \text { mo } \\
\text { after diagnosis }\end{array}$ & None & None \\
\hline 14 & 59 & $\mathrm{~F}$ & Uterus & Local excision & $\begin{array}{c}\mathrm{LS} \\
(\mathrm{G} 3)\end{array}$ & $\begin{array}{l}\text { Alive } 25 \text { mo } \\
\text { after diagnosis } \\
5 \text { cycles }\end{array}$ & $\begin{array}{l}\text { Carboplatin/ } \\
\text { paclitaxel }\end{array}$ & Liver $(\mathrm{m}) / 25 \mathrm{mo}$ \\
\hline 15 & 54 & $\mathrm{~F}$ & Upper arm & Local excision & $\begin{array}{c}\mathrm{LS} \\
(\mathrm{G} 2)\end{array}$ & $\begin{array}{l}\text { Alive } 40 \text { mo } \\
\text { after diagnosis }\end{array}$ & None & None \\
\hline
\end{tabular}


Table I. Continued.

\begin{tabular}{|c|c|c|c|c|c|c|c|c|}
\hline $\begin{array}{l}\text { No. of } \\
\text { patient }\end{array}$ & Age & Sex & $\begin{array}{l}\text { Relation to } \\
\text { vessel, size }\end{array}$ & Procedure & $\begin{array}{l}\text { Histology } \\
\text { (grading) }\end{array}$ & Follow-up & $\begin{array}{c}\text { Additional } \\
\text { treatment }\end{array}$ & $\begin{array}{l}\text { Recurrence/ } \\
\text { time after } \\
\text { diagnosis }\end{array}$ \\
\hline 16 & 67 & M & Leg & Biopsy & $\begin{array}{c}\mathrm{LS} \\
\text { (G3) }\end{array}$ & $\begin{array}{l}\text { Died } 5 \text { mo } \\
\text { after diagnosis }\end{array}$ & $\begin{array}{l}\text { Epirubicin } \\
1 \text { cycle }\end{array}$ & Lung $(\mathrm{m}) / 5 \mathrm{mo}$ \\
\hline 17 & 60 & $\mathrm{~F}$ & $\begin{array}{l}\text { Retro- } \\
\text { peritoneal }\end{array}$ & Local excision & $\begin{array}{c}\mathrm{LS} \\
\text { (G3) }\end{array}$ & $\begin{array}{l}\text { Died } 17 \text { mo } \\
\text { after diagnosis }\end{array}$ & $\begin{array}{l}\text { Etoposide/ } \\
\text { adriamycin/ } \\
\text { ifosfamide }\end{array}$ & Local (r)/7 mo \\
\hline 18 & 56 & $\mathrm{~F}$ & Uterus & Hysterectomy & Leiomyoma & - & - & - \\
\hline 19 & 43 & $\mathrm{~F}$ & Uterus & Hysterectomy & Leiomyoma & - & - & - \\
\hline
\end{tabular}

PT, pulmonary trunk; PA, pulmonary artery; RV, right ventricle; (r), recurrence; LS, leiomyosarcoma; IS, intimal sarcoma; (m), metastasis; mo, months.

and Flt-1 receptor mutants (13) have shown the potential of the VEGF system as therapeutic targets.

There is strong evidence that microvessel density in the area of most intense neovascularization is an independent prognostic factor for overall and relapse-free survival in a variety of carcinomas $(14,15)$, cutaneous melanomas $(16)$ and lymphoma (17). In addition, a significantly higher number of microvessels were observed in colon carcinomas with liver metastasis compared with non-metastatic tumors (18). However, there are differences in angiogenesis between sarcomas and carcinomas (19). Thus the prognostic value of MVD in sarcomas is still controversially discussed. For example, Kawauchi and coworkers found no correlation between VEGF expression and microvessel density and the overall survival (20). Another publication described no correlation between MVD, p53 expression and survival time (21). On the other hand an increased neovascularization could be demonstrated in high-grade malignant myxofibrosarcoma compared to their low-grade malignant counterparts, whereas no correlation was found for myxoid liposarcoma and myxoid round cell liposarcoma (22).

To further investigate the role of MVD in a series of sarcomas we have analyzed microvessels in hot spots of sarcomas of the pulmonary artery and poorly differentiated leiomyosarcomas and correlated the data with the expression of angiogenic factors and patient survival.

\section{Materials and methods}

Patients. Between 1989 and 2001 tissues samples from sarcomas of the pulmonary artery ( 7 intimal sarcomas; 5 cases G2; 2 cases G3) were obtained from 7 patients undergoing surgical tumor resection and pulmonary artery reconstruction because of chronic pulmonary embolism. The Department of Cardiovascular Surgery of the Johannes Gutenberg University at Mainz provided all samples. In addition, 10 cases of leiomyosarcomas of deep soft tissue ( 3 cases G2; 7 cases G3) were collected from the Department of General and
Abdominal Surgery and 4 academic hospitals of the University of Mainz between 1992 and 2001. Two uterine leiomyomas (1 pre-menopausal, 1 post-menopausal) were examined as disease controls. Normal control specimens from pulmonary arteries were collected from the archives of the Institute of Pathology and Neuropathology, University of Mainz. Immediately after surgery, tissue samples were fixed in $4 \%$ buffered formaldehyde and embedded in paraffin. In 15 patients tumors were excised completely and one patient incompletely. In one patient only a tumor biopsy was performed. In addition, 11 patients received a regimen of polychemotherapy and/or radiation. Patient data and followup were obtained from the patient records and clinical history and are listed in an anonymous fashion in Table I. The study was performed in complete accordance with the criteria for the use of patient archive material, as laid down by the responsible ethics committees.

Immunohistochemical staining: Avidin-Biotin-Complex. Immunohistochemical staining was performed on $5 \mu \mathrm{m}$ sections as summarized in Table II. Alternatively to the ABC method, factor VIII stains were performed using the Dako Envision ready-to-use kit ${ }^{\circledR}$ (Dako, Hamburg, Germany) also connected with peroxidase and developed with the AEC substrate kit. The sections were counterstained with hematoxylin and mounted with Aquatex ${ }^{\circledR}$ (Merck, Darmstadt, Germany). In control sections, the primary antibody was either omitted or substituted with non-specific rabbit immunoglobulins.

Alkaline phosphatase immunohistochemical staining. Double-labeling was performed on 4 randomly selected cases using the Dako Envision staining Kit with AEC first for factor VIII and as a second step the ABC-Alkaline Phosphatase method with the monoclonal antibody against VEGFR-2 as follows: briefly, sections were dewaxed according to a standard protocol an pre-treated with $2 \% \mathrm{H}_{2} \mathrm{O}_{2}$ for 30 min at room temperature (RT). After a washing step in phosphatebuffered saline (PBS) the slides were placed in $10 \mathrm{mM}$ citrate 
Table II. Antibody types and source used in this study.

\begin{tabular}{|c|c|c|c|c|c|c|}
\hline Antibody & Antigen & Provider & Dilution & Epitope retrieval & Incubation & Control \\
\hline Mouse IgG1 & $\begin{array}{l}\text { VEGFR-1 } \\
\text { Clone C-17 }\end{array}$ & $\begin{array}{l}\text { Santa Cruz Biotechnology, } \\
\text { Heidelberg, Germany }\end{array}$ & $1: 100$ & $\begin{array}{l}6 \times 5 \mathrm{~min} \text { in citrate buffer } \\
\mathrm{pH} 6.0 \text { at } 500 \mathrm{~W}\end{array}$ & Overnight RT & Umbilical vein \\
\hline Mouse IgG1 & $\begin{array}{l}\text { VEGFR-2 } \\
\text { Clone A-3 }\end{array}$ & $\begin{array}{l}\text { Santa Cruz Biotechnology, } \\
\text { Heidelberg, Germany }\end{array}$ & $1: 50$ & $\begin{array}{l}40 \text { min in citrate buffer } \\
\mathrm{pH} 6.0 \text { at } 240 \mathrm{~W}\end{array}$ & Overnight RT & Colon carcinoma \\
\hline Rabbit IgG1 & $\begin{array}{l}\text { Factor VIII } \\
\text { polyclonal }\end{array}$ & $\begin{array}{l}\text { Dako, Hamburg, } \\
\text { Germany }\end{array}$ & $1: 200$ & $\begin{array}{l}30 \text { min in citrate buffer } \\
\mathrm{pH} 6.0 \text { at } 240 \mathrm{~W}\end{array}$ & $1 \mathrm{~h} \mathrm{RT}$ & Colon carcinoma \\
\hline Rabbit IgG1 & $\begin{array}{l}\text { VEGF } \\
\text { polyclonal }\end{array}$ & $\begin{array}{l}\text { Zymed Laboratories Inc., } \\
\text { San Francisco, CA, USA }\end{array}$ & $1: 50$ & $\begin{array}{l}4 \times 5 \text { min in citrate buffer } \\
\text { pH } 6.0 \text { at } 800 \mathrm{~W}\end{array}$ & Overnight RT & Colon carcinoma \\
\hline
\end{tabular}

RT, room temperature.

buffer ( $\mathrm{pH}$ 6.0) for $30 \mathrm{~min}$ at $240 \mathrm{~W}$. After an additional washing step the first antibody (factor VIII) was applied for $1 \mathrm{~h}$ at RT. Again sections were washed with PBS and Dako Envision-HRP Kit was incubated according to the manufacturer's recommendations. Finally, the horseradish peroxidase was coupled with AEC and the staining was developed under microscopic control and counterstained with hematoxylin. After washing with TRIS- $\mathrm{HCl}$ the slides were incubated for $1 \mathrm{~h}$ at room temperature (RT) or overnight at $4^{\circ} \mathrm{C}$ with the primary antibody diluted 1:50 (VEGFR-2) in TRIS-HCl ( $\mathrm{pH} 7.6)$. The sections were then rinsed in TRIS$\mathrm{HCl}(\mathrm{pH}$ 7.6) and incubated for $30 \mathrm{~min}$ at RT with a secondary goat anti-mouse IgG antibody (Jackson Immunoresearch, West Grove, PA, USA) in a 1:200 dilution in TRIS-NaCl (pH 7.6). The Avidin Biotin complex (Vector Laboratories, Burlingam, CA, USA) was then incubated for $30 \mathrm{~min}$ at RT in a 1:100 TRIS-HCl ( $\mathrm{pH} 7.6)$ followed by the addition of NBT/BCIP with Levamisol substrate in TRIS-HCl (pH 9.7). Color development was stopped under microscopic control by adding a mixture of TRIS-HCl ( $\mathrm{pH}$ 7.6). Negative controls were performed as detailed above. Two colon carcinomas known to be positive for both molecules served as positive controls.

Microscopical analysis. The specimens were analyzed by light microscopy (Zeiss Axiophot, Göttingen, Germany) by two different observers (AG, GS) as follows. The extent of the immunostaining for VEGF, VEGFR-1 and VEGFR-2 was estimated by counting the number of positive cells/10 high power fields (HPF). Results were classified according to 5 categories: 0 , negative; 1 , between 1 and $25 \%$ of cells positive; 2, between 26 and $50 \%$ of cells positive; 3 between 51 and $75 \%$ of cells positive; 4 , between 76 and $100 \%$ of cells positive.

In factor VIII staining two independent observers (AG, GS) examined up to 5 different sections per sarcoma as described previously (23) and according to the international consensus guidelines (24). Briefly, sections were scanned at low magnification to identify the highest vascularized areas (hot spots). The hot spot areas were digitized with an image analysis program (MIDOK II, Technical Office Hilgers, Germany). All examinations were performed in a blinded manner without knowledge of clinical parameters. Within the hot spots the vascular densities were evaluated by measuring the intervascular distances and vascular surface area by means of an image analysis program (KS 300, Carl Zeiss Vision, Eching, Germany).

Statistics. Analyses were performed using SigmaStat and SigmaPlot for Windows (SPSS Scientific Software, Erkrath, Germany). Continuous variables not following the normal distribution were compared between two or more groups with the Mann-Whitney rank sum test. The Wilcoxon signed rank test was used to compare related samples. For the MVD, IVD, as well as the VSA the median for each group was calculated. Univariate analyses of time to death due to the sarcomas or time of recurrence (relapse-free survival) were performed using the product-limit procedure (Kaplan-Meier method), with data of histological diagnosis as the starting point. Patients who died of other causes were censored at the time of death. Differences between categories were tested by the log-rank test. Statistically significant differences were considered to be present at a value of $\mathrm{p}<0.05$.

\section{Results}

Evaluation of microvessel density. The microvessels were counted in areas without necrosis and in vital tumor areas in close proximity to necrosis (Fig. 4A). Only sections with accurate factor VIII staining were evaluated. In SPA's a statistically significant higher vessel count was detected in areas with necrosis $(47 \pm 3)$ compared to those without necrosis $(31 \pm 1 ; \mathrm{p}<0.001)$. Adjacent tumor-free collagenous tissue had a significantly lower vessel count $(18 \pm 1)$ compared to tumor tissue $(\mathrm{p}<0.001)$ (data not shown). On the other hand, the comparison of areas with $(38 \pm 5)$ and without necrosis $(47 \pm 5)$ in the leiomyosarcomas of other origin showed no significant difference $(\mathrm{p}=0.349)$. The surrounding tumor free smooth muscle tissue in the latter group had a highly variable, but in general, significantly higher vessel density $(121 \pm 9)$ compared 


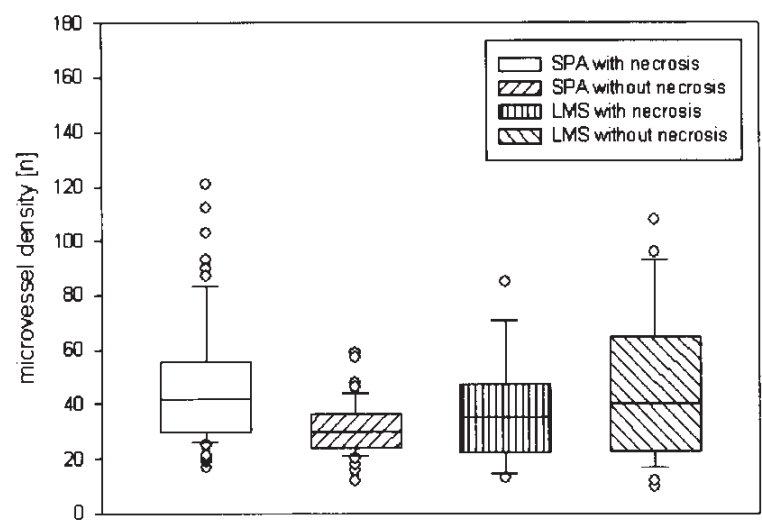

Figure 1. Box plots showing the microvessels density of SPA and leiomyosarcomas without necrosis and at the border of necrosis. The lowest vessel count could be seen for SPA without necrosis, which was significant lower compared to SPA at sites of necrosis $(\mathrm{p}<0.001)$.

to all other groups even when compared to the tumor-free tissue of the SPA group $(\mathrm{p}<0.001)$ (data not shown). Comparing the SPA and the leiomyosarcomas of other origin no significant difference could be seen in areas with $(\mathrm{p}=0.097)$ and without necrosis ( $\mathrm{p}=0.027$ ) (Fig. 1). In the leiomyomas of the uterus a significant lower count of microvessels could be detected compared to the sarcomas (data not shown). In addition, we compared the MVD of patients developing metastasis with the patients without metastases. Only SPA $(\mathrm{p}=0.037)$ but not the leiomyosarcomas of other origin $(\mathrm{p}=1.0)$ revealed a statistically significant difference. The median values for both groups in SPA were close together (39 with metastasis/32 without metastasis) therefore it was hard to define a cut-off level to predict metastasis from the MVD levels. The results are summarized in Table III.

Evaluation of the vascular surface area. Morphometrical analysis of the vascular surface (VSA) displayed 3.47 $\pm 0.39 \%$ of the total tumor area for SPA and a slightly higher VSA of $4.24 \pm 0.59 \%$ for leiomyosarcomas (with and without necrosis) which was however not significantly different $(\mathrm{p}=0.648)$. Comparing the VSA at sites of necrosis of SPA $(4.67 \pm 0.76 \%)$ with leiomyosarcomas of other origin $(6.56 \pm 1.32 \%)$ there was no statistically significant difference $(\mathrm{p}=0.235)$. The same was found comparing the two groups without necrosis (SPA $2.91 \pm 0.3 \%$ vs. leiomyosarcomas $2.88 \pm 0.51)(\mathrm{p}=0.38)$. The comparison of SPA with necrosis and without necrosis and for leiomyosarcomas of different origin revealed a statistically significant difference $(\mathrm{p}=0.01)$ and $(\mathrm{p}=0.005)$ respectively (Fig. 2). The comparison of VSA among the groups with and without metastasis showed only a difference in the SPA

Table III. Microvasculature and VEGF/VEGFR-expression in SPA and leiomyosarcomas of other origin.

\begin{tabular}{|c|c|c|c|c|c|c|c|c|}
\hline \multirow[b]{2}{*}{$\begin{array}{l}\text { No. of } \\
\text { patient }\end{array}$} & \multicolumn{2}{|c|}{ Microvessel count } & \multicolumn{2}{|c|}{ VEGF } & \multicolumn{2}{|c|}{ VEGFR-1 } & \multicolumn{2}{|c|}{ VEGFR-2 } \\
\hline & $\begin{array}{c}\text { With } \\
\text { necrosis }\end{array}$ & $\begin{array}{l}\text { Without } \\
\text { necrosis }\end{array}$ & Vessel & $\begin{array}{l}\text { Tumor } \\
\text { cells }\end{array}$ & $\begin{array}{l}\text { MNC/ } \\
\text { vessels }\end{array}$ & $\begin{array}{l}\text { Tumor } \\
\text { cells }\end{array}$ & Vessel & $\begin{array}{l}\text { Tumor } \\
\text { cells }\end{array}$ \\
\hline 1 & $49.82 \pm 4.4$ & $27.77 \pm 1.1$ & + & ++++ & $++/+$ & - & - & + \\
\hline 2 & $28.62 \pm 2.1$ & $18 \pm 3.1$ & - & ++++ & $++/+$ & + & - & + \\
\hline 3 & Excluded & Excluded & - & +++ & $+++/+$ & ++ & - & - \\
\hline 4 & $47.29 \pm 4.1$ & $34.92 \pm 2.7$ & + & ++ & $+/-$ & + & - & - \\
\hline 5 & $45.00 \pm 7.0$ & $25.25 \pm 1.8$ & - & ++++ & $++/+$ & + & - & + \\
\hline 6 & $54.09 \pm 4.0$ & & + & ++++ & $++/++$ & ++ & ++++ & ++++ \\
\hline 7 & $52.75 \pm 11.5$ & $36.9 \pm 2.6$ & ++ & +++ & $++/+$ & ++ & ++++ & ++++ \\
\hline 8 & Excluded & Excluded & + & ++ & $+/-$ & +++ & - & ++ \\
\hline 9 & 21.00 & $21.00 \pm 4.0$ & + & + & $+/-$ & + & + & ++ \\
\hline 10 & 65.00 & $64.85 \pm 9.1$ & + & + & $++/+$ & - & ++ & ++ \\
\hline 11 & & $51.14 \pm 3.8$ & + & - & $++/+$ & - & - & - \\
\hline 12 & $24 \pm 3.7$ & $16.75 \pm 3.4$ & ++ & +++ & $+++/+$ & - & +++ & + \\
\hline 13 & & $22.5 \pm 4.5$ & + & + & $+/-$ & ++++ & ++ & ++ \\
\hline 14 & $42.33 \pm 2.7$ & & + & +++ & $++/+$ & + & + & +++ \\
\hline 15 & & $37.00 \pm 5.6$ & + & +++ & $++/-$ & + & + & +++ \\
\hline 16 & $44.00 \pm 10.0$ & $21.00 \pm 1.0$ & ++ & +++ & $+++/+$ & - & - & - \\
\hline 17 & 48.00 & $68.60 \pm 14.8$ & ++ & ++++ & $+/-$ & ++++ & + & ++++ \\
\hline 18 & - & $34.00 \pm 1.7$ & + & + & $+/-$ & - & + & + \\
\hline 19 & - & $35.67 \pm 1.2$ & + & + & $+/-$ & - & + & + \\
\hline
\end{tabular}

MNC, mononuclear cells. 


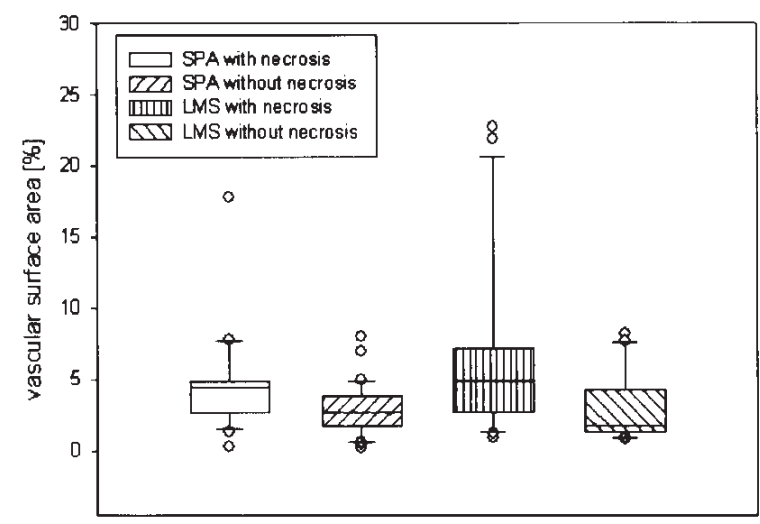

Figure 2. The evaluation of the vascular surface area revealed higher levels at sites of necrosis compared to areas without necrosis ( $\mathrm{p}=0.01$ for SPA; $\mathrm{p}=0.005$ for leiomyosarcomas).

group ( $\mathrm{p}=0.04)$. The median values were $3.995 \%$ for SPA with metastasis and 2.38 for SPA without metastasis. The results are summarized in Table III.

Evaluation of intervascular distances. The evaluation of the intervascular distances in areas of highest vascularisation (areas with necrosis and areas without necrosis) revealed a significant difference between the two groups [SPA $(85.77 \pm 2.19 \mu \mathrm{m}) \mathrm{vs}$. leiomyosarcomas of other origin $(68.31 \pm 1.31 \mu \mathrm{m}) ;(\mathrm{p}<0.001)$; data not shown]. The intervascular distances at sites of necrosis were nearly identical in SPAs $(64.11 \pm 2.11 \mu \mathrm{m})$ and leiomyosarcomas of other origin [67.94 $\pm 2.5 \mu \mathrm{m}(\mathrm{p}=0.092)]$ (Fig. 3A). In the non-necrotic areas of both groups the intervascular distances were significant lower in leiomyosarcomas of other origin $(68.49 \pm 1.5 \mu \mathrm{m})$ than in the SPA $(110.13 \pm 3.67 \mu \mathrm{m})(\mathrm{p}<0.001)$ (Fig. 3B). The leiomyosarcomas of other origin revealed a slightly higher intervascular distance in non-necrotic areas compared to those at sites of necrosis but this difference was not significant $(\mathrm{p}=0.282)$. However, when comparing nonnecrotic areas with areas showing necrosis in the SPA group a statistically significant difference was seen $(p<0.001)$.
When comparing IVD of patients with and without metastasis there was only a significant difference in SPAs $(\mathrm{p}<0.001)$ but not in leiomyosarcomas of other origin $(\mathrm{p}=0.881)$. The median values of the groups were 62.5 vs. $79.8 \mu \mathrm{m}$ for SPA and 60.7 vs. $62.1 \mu \mathrm{m}$ for leiomyosarcomas (metastasized vs. non-metastasized). The results are summarized in Table III.

Overall survival of SPA vs. leiomyosarcomas. There was a slightly longer overall survival in patients with SPA, however the difference was not significant $(p=0.91)$. The relapse-free survival did not differ significantly between SPA and leiomyosarcomas $(\mathrm{p}=0.92)$ (data not shown). Thus, we have pooled the data and investigated the influence of the expression of angiogenic factors on the overall survival in the primary tumors as well as for the relapse-free survival. Further analysis of survival data revealed that the occurrence of metastasis significantly decreases the survival time $(p<0.03)$ (data not shown). Concerning MVD, IVAS and VSA we formed two groups (e.g. MVD high and MVD low) and related them to survival data. We could not establish any difference for overall or relapse-free survival between the different groups (data not shown).

VEGF expression. The semi-quantitative scoring of the VEGF expression revealed a high expression in tumor cells in all SPA, which was more pronounced at the border of necrosis (Fig. 4B). There was a significantly lower expression of VEGF in the leiomyosarcomas of other origin $(p=0.04)$, although there was a more heterogeneous distribution in the different cases. The semi-quantitative assessment is shown in Table III. In addition, all cases showed marked to moderate positivity for VEGF in inflammatory cells. One leiomyoma of the uterus displayed high expression of VEGF in the endometrial glands (proliferation phase, pre-menopausal) as well as the associated vessels of the endometrial stroma. The post-menopausal case revealed only few positive cells in the endometrium and adjacent vessels. Both cases revealed only a low, scattered positive staining in normal smooth muscle cells and vessels and to a lesser extent in the leiomyomatous nodules for VEGF. The overall $(\mathrm{p}=0.15)$ and relapse-free survival $(\mathrm{p}=0.42)$ was
A

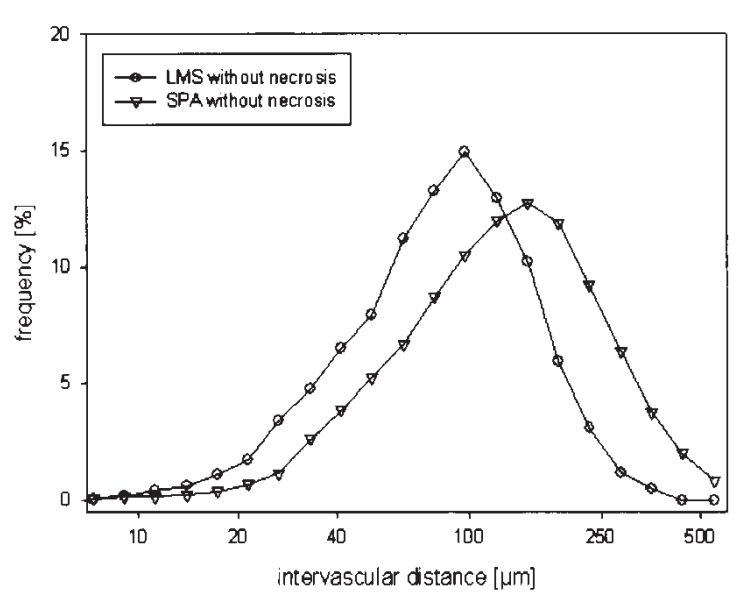

B

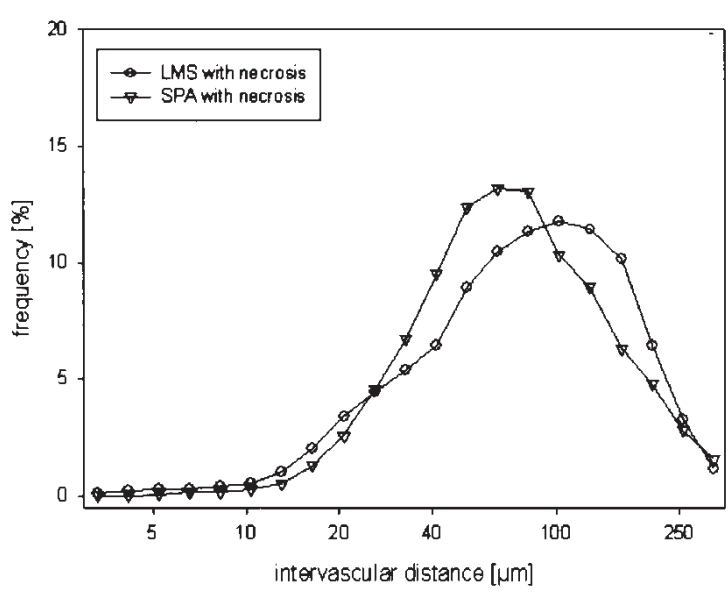

Figure 3. Smaller intervascular distances were observed for leiomyosarcomas compared to SPA at areas without necrosis, which was statistically significant different $(\mathrm{p}<0.001)$. The comparison of leiomyosarcomas and SPA without necrosis, however, revealed slightly lower distances for SPA, which was not statistically different $(\mathrm{p}=0.092)$. 

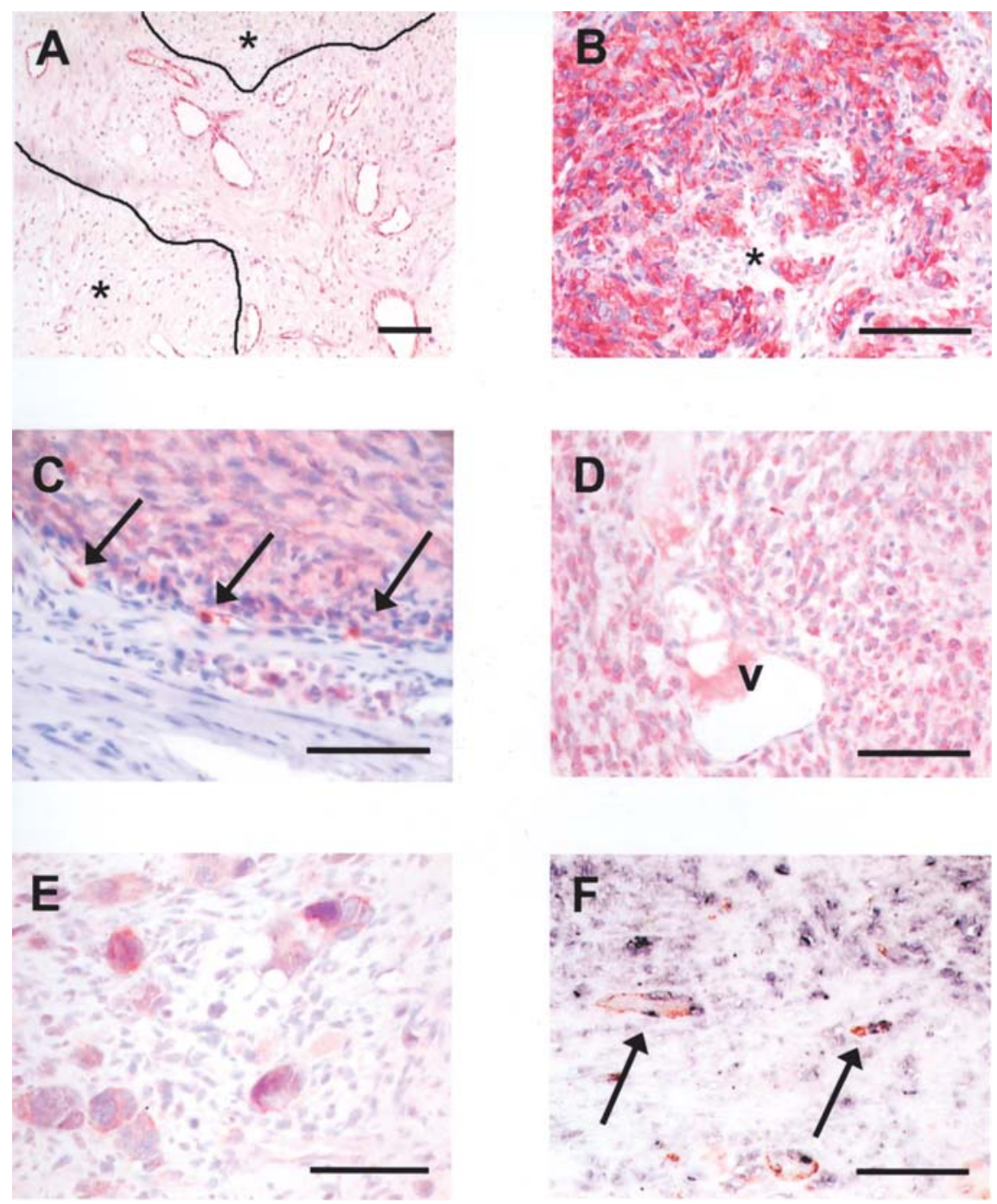

Figure 4. (A) Shows a dense vascularisation at the border of necrosis (asterisk) in an intimal sarcoma (ABC; AEC; magnification x10, 100 $\mu$ m). (B) Shows very marked expression VEGF at sites of necrosis (asterisk) in sarcoma cells. (Envision ${ }^{\circledR}$; AEC; magnification x20, $100 \mu$ m). VEGFR-1 was weakly expressed in the sarcoma cells but present in mononuclear cells (arrow) (C) (ABC; AEC; magnification x40; $50 \mu$ m). VEGFR-2 was present in the sarcoma cells as well as associated vessels (v) (D). Some cases showed a prominent staining in large sarcoma cells with marked atypia (E) (ABC; AEC; magnification x20, $100 \mu \mathrm{m}$ ). (F) Shows a subset of tumor vessels (factor VIII; red), which coexpress VEGFR-2 (black) in a leiomyosarcomas (Envision; AEC; magnification $\mathrm{x} 40,50 \mu \mathrm{m})$.

not significantly different between VEGF positive/negative cases (data not shown).

VEGFR-1 expression. VEGFR-1 was expressed in a small proportion of tumor microvessels, but also in some vessels at the tumor capsule as well as in adjacent tumor-free tissue. There was a weak to moderate staining for this receptor in sarcoma cells in most examined cases, which was not significantly different between SPA and leiomyosarcomas of different origin $(\mathrm{p}=0.696)$. However, numerous mononuclear cells could be markedly labeled with the antibody against the receptor (Fig. 4C). The data are summarized in Table III. In the leiomyomas and the uteri a unique weak staining for smooth muscle cells, endometrial glands as well as stromal vessels was seen. Concerning the survival analysis no significant difference in the overall survival for patients positive for VEGFR-1 compared to those lacking VEGFR-1 expression ( $\mathrm{p}=0.961)$ could be detected. The same was true for the examination of relapse-free survival $(\mathrm{p}=0.57)$ (data not shown).

VEGFR-2 expression. VEGFR-2 was detected with a strong signal only in two out of 7 pulmonary sarcomas in tumorassociated vessels. In contrast, most leiomyosarcomas had a moderate to high expression of this molecule in the vessel endothelium. In addition, we observed a moderate to high expression of VEGFR-2 in tumor cells (Fig. 4D) in most examined cases of leiomyosarcoma and SPA, although the differences were not significant $(\mathrm{p}=0.769)$. Interestingly, in cases of low expression the large anaplastic cellular subtype was positive for VEGFR-2 (Fig. 4E). The examination of leiomyomas of the uterus revealed a weak staining for normal smooth muscle cells, leiomyoma nodules, and associated vessels, whereas the endometrial glands and the stroma vessels were strongly positive for VEGFR-2 in the pre-menopausal case (proliferation phase). The data are 
summarized in Table III. Concerning survival analysis we could not detect a significant difference in overall survival for patients positive for VEGFR-2 compared to those lacking VEGFR-2 expression ( $\mathrm{p}=0.232$ ). There was also no difference between the two groups concerning the relapse-free survival $(\mathrm{p}=0.674)$ (data not shown).

Double labeling of VEGFR-2 and factor VIII. In the examined cases most tumor cells were positive for VEGFR-2 as already mentioned. In addition, numerous factor VIII positive endothelial cells within the tumors could be double labeled with both molecules (Fig. 4F). The number of positively stained endothelial cells was slightly more pronounced at the border of necrosis and at the sites of tumor invasion. Only few double-labeled cells could be observed in adjacent tumor-free tissue. Comparable staining results were obtained for colon carcinomas used as positive control (data not shown).

\section{Discussion}

Sarcomas of the pulmonary artery as well as poorly differentiated leiomyosarcomas of other origin have a poor prognosis with rapid progression despite extensive therapy. Since conventional chemotherapy is of limited effect it is necessary to define new potential therapeutic strategies in order to improve patient outcome. In recent years the tumor vasculature has attracted attention based on the hypothesis that disruption of the outgrowth of new blood vessels may induce shrinkage of the tumor due to lack of oxygen and nutrients. Thus, it is of importance to investigate the tumor vasculature of sarcomas of the pulmonary artery and the expression of angiogenic factors in order to provide a basis for possible anti-angiogenic therapy.

In the present study we show that angiogenesis plays an important role in the understanding of the tumor biology of the sarcomas. Based on previous reports, the significance of microvessel count as an independent prognostic factor and the role of molecules involved in this process has been emphasized in a variety of tumors (14). In our study we could show a significant difference for MVD, IVD and VSA between the groups with and without metastasis for the SPAs, supporting the notion that analysis of the vasculature may predict the potential of metastasis $(25,26)$. In addition, we were not able to detect a difference in overall or diseasefree survival in either sarcoma group for the MVD or the other morphometric parameters. The difference can in part be explained by the fact that Weidner and coworkers compared for example a large number of patients of node-positive and node-negative breast carcinomas. In contrast, in our small series most patients developed metastases shortly after diagnosis. Thus, our results are not directly comparable to these previous reports.

In addition, we could not demonstrate a difference in MVD between SPA and leiomyosarcomas of other origin but both groups were better vascularized than leiomyomas of the uterus. This is in contrast to a recent report of uterine leiomyoma and leiomyosarcoma showing no significant difference of microvessel density between these two groups (27). This could be due to the fact that in our series the sarcomas developed at different anatomic sites (e.g. limbs, uterus, retroperitoneum) and that they may have a different behavior, leading to a stronger angiogenic response. This view is supported by the fact that most of our patients had numerous areas of necrosis and subsequently due to hypoxia a high expression of VEGF and VEGFR-2 and to a lesser extent VEGFR-1. Another study has found that in carcinosarcomas of the uterus MVD of the epithelial element was significantly higher than that of the mesenchymal element. Moreover, the epithelial element showed a higher VEGF expression than the mesenchymal element (28). We have observed in our cases a marked expression of VEGF in the sarcomas whereas VEGF expression in leiomyomas was low to absent, emphasizing that a dense neovascularisation is triggered by a strong expression of VEGF. The unique high expression of VEGF in SPA in our series was paralleled by the occurrence of necrosis in these cases, whereas leiomyosarcomas of other origin varied in VEGF expression and developed less necrosis. Interestingly, SPA revealed a higher number of microvessels at sites of necrosis compared to areas without necrosis, which was not the case for the leiomyosarcomas of other origin. These results are in line with the hypothesis that due to local hypoxia within the tumor the transcriptionally up-regulation of VEGF leads to an induction of vessel outgrowth via interaction of VEGF with its corresponding receptors (29). The generally higher vessel density, vascular surface area and lower intervascular distances of leiomyosarcomas of other origin compared to the SPA could be explained by the difference of vascular density in the surrounding non-tumorous tissue. In SPA the vessel walls were almost completely substituted by tumor formation surrounded by scar tissue with relatively low vascularisation. In contrast, numerous vessels provided by the surrounding muscle compartment mostly nourished leiomyosarcomas of other origin. These findings further support the view that the leiomyosarcomas of other origin develop less foci of necrosis since there is probably less oxygen deficit due to the higher vessel density compared to SPA.

Since it has been described that vessel co-option promotes tumor growth (30), one can speculate that this mechanism may play a substantial role for leiomyosarcomas of other origin. The co-option promotes tumor growth along preexisting host vessels with subsequent vessel remodeling by endothelial regression, apoptosis and new vessel outgrowth (31). This process of vessel co-option is triggered by angiopoetins and their receptors whereas angiogenesis is mainly driven by VEGFR-2. We were able to demonstrate a moderate to strong expression of VEGFR-2 in tumor vessels supporting the view that angiogenesis plays an important role in these tumors. However, this does not exclude the possibility that vessel co-option may also take place in these tumors. It is also known that VEGFR-2 in contrast to VEGFR-1 is the most potent mitogen for endothelial cells. Thus, we were able to demonstrate numerous microvessels expressing VEGFR-2 at sites of necrosis in SPA as well as in leiomyosarcomas of other origin. In contrast, the expression of VEGFR-1 was moderate to low for vessels in these areas. The VEGFR-1 gene is regulated by hypoxia in HUVECS (32) and pericytes (33) due to a binding site of HIF-1 $\alpha$, which is not present on VEGFR-2. However, under hypoxic conditions and in the 
presence of VEGF-A an increased expression of VEGFR-2 as an indirect effect could be observed (34). The examined specimens revealed a prominent expression of VEGFR-2 but lower presence of VEGFR-1, demonstrating that the latter mechanism may play a more important role in the tumor growth of the sarcomas. In addition, it is known that VEGFR-1 is also present on monocytes, which are able to migrate towards VEGF (35). Since we have found numerous VEGFR-1 positive mononuclear cells in our series these cells may be attracted by the high expression of VEGF in the tumors. This could be an important mechanism in the host defense against the tumor.

We have further addressed another issue in our investigation concerning the expression of VEGFR-2 in sarcoma cells. There is increasing evidence in the literature suggesting an autocrine mechanism for tumor cells to be stimulated via the VEGF/VEGFR system, thus leading to an enhanced proliferation/migration (36). Thus, secreted VEGF is not only able to interact with its receptors expressed on endothelial cells but also with neighboring tumor cells leading to a perpetuated activation loop. We observed in our double labeling experiments some microvessels mostly at the tumor border, which were positive for factor VIII but also for VEGFR-2. However, most VEGFR-2 positive cells were negative for factor VIII and therefore should be tumor cells. In addition, we have investigated leiomyosarcoma cell lines and found also an expression of VEGF-receptors, which could be stimulated by VEGF (unpublished data). These results suggest that anti-angiogenic drugs may not only target VEGF-receptors in the tumor-associated microvessels but also directly tumor cells. However, the disruption of the VEGFR signal alone will not be sufficient to inhibit tumor growth. On the other hand it has already been shown that antibodies directed against VEGFR-1 and VEGFR-2 effectively inhibit the growth of leukemia in vitro and in vivo in mice (37). Thus, the blocking of VEGF receptors may be a novel promising tool for anti-cancer therapy in sarcomas, which should be addressed in the near future.

Our data provide strong evidence that morphometry of the tumor vasculature separates sarcomas of the pulmonary artery from leiomyosarcomas of other origin. In addition, MVD and other parameters may predict metastasis but not overall and relapse-free survival. The strong expression of VEGF receptors on endothelial cells and tumor cells support the view that these aggressive neoplasms may benefit from anti-angiogenic therapy.

\section{Acknowledgements}

The authors wish to acknowledge the excellent technical support of Kerstin Bahr and Sandra Gerecht. This publication contains data of the dissertation thesis of Gero Schermutzki. This study and A.K.A.G. were in part supported by a grant of the Deutsche Forschungsgemeinschaft to M.A.K. (KO 1050/ 6-1).

\section{References}

1. Mingoli A, Cavallaro A, Feldhaus RJ, et al: Inferior vena cava leiomyosarcoma: establishment of an international registry. Eur J Vasc Surg 8: 380-381, 1994.
2. McGlennen RC, Manivel JC, Stanley SJ, et al: Pulmonary artery trunk sarcoma: a clinicopathologic, ultrastructural, and immunohistochemical study of four cases. Mod Pathol 2: 486-494, 1989.

3. Burke AP and Virmani R: Sarcomas of the great vessels. A clinicopathologic study. Cancer 71: 1761-1773, 1993.

4. Hottenrott G, Mentzel T, Peters A, Schroder A and Katenkamp D: Intravascular ('intimal') epithelioid angiosarcoma: clinicopathological and immunohistochemical analysis of three cases. Virchows Arch 435: 473-478, 1999.

5. Mayer E, Kriegsmann J, Gaumann A, et al: Surgical treatment of pulmonary artery sarcoma. J Thorac Cardiovasc Surg 121: 77-82, 2001.

6. Gaumann A, Tews DS, Mentzel T, et al: Expression of drug resistance related proteins in sarcomas of the pulmonary artery and poorly differentiated leiomyosarcomas of other origin. Virchows Arch 442: 529-537, 2003.

7. Folkman J: Angiogenesis in cancer, vascular, rheumatoid and other disease. Nat Med 1: 27-31, 1995.

8. Carmeliet P: Angiogenesis in health and disease. Nat Med 9: 653-660, 2003.

9. Issbrucker K, Marti HH, Hippenstiel S, et al: p38 MAP kinase a molecular switch between VEGF-induced angiogenesis and vascular hyperpermeability. FASEB J 17: 262-264, 2003.

10. Matsumoto $\mathrm{T}$ and Claesson-Welsh L: VEGF receptor signal transduction. Sci STKE 2001: RE21, 2001.

11. Paradis V, Lagha NB, Zeimoura L, et al: Expression of vascular endothelial growth factor in renal cell carcinomas. Virchows Arch 436: 351-356, 2000

12. Cheng N, Brantley DM, Liu H, et al: Blockade of EphA receptor tyrosine kinase activation inhibits vascular endothelial cell growth factor-induced angiogenesis. Mol Cancer Res 1: 2-11, 2002.

13. Heidenreich R, Machein M, Nicolaus A, et al: Inhibition of solid tumor growth by gene transfer of VEGF receptor-1 mutants. Int J Cancer 111: 348-357, 2004.

14. Weidner N: Angiogenesis as a predictor of clinical outcome in cancer patients. Hum Pathol 31: 403-405, 2000.

15. Li C, Gardy R, Seon BK, et al: Both high intratumoral microvessel density determined using CD105 antibody and elevated plasma levels of CD105 in colorectal cancer patients correlate with poor prognosis. Br J Cancer 88: 1424-1431, 2003.

16. Straume O and Akslen LA: Expresson of vascular endothelial growth factor, its receptors (FLT-1, KDR) and TSP-1 related to microvessel density and patient outcome in vertical growth phase melanomas. Am J Pathol 159: 223-235, 2001.

17. Hazar B, Paydas S, Zorludemir S, Sahin B and Tuncer I: Prognostic significance of microvessel density and vascular endothelial growth factor (VEGF) expression in non-Hodgkin's lymphoma. Leuk Lymphoma 44: 2089-2093, 2003.

18. Tomisaki S, Ohno S, Ichiyoshi Y, et al: Microvessel quantification and its possible relation with liver metastasis in colorectal cancer. Cancer 77: 1722-1728, 1996.

19. Tomlinson J, Barsky SH, Nelson S, et al: Different patterns of angiogenesis in sarcomas and carcinomas. Clin Cancer Res 5: 3516-3522, 1999.

20. Kawauchi S, Fukuda T and Tsuneyoshi M: Angiogenesis does not correlate with prognosis or expression of vascular endo-thelial growth factor in synovial sarcomas. Oncol Rep 6: 959-964, 1999.

21. Theegarten D, Zorn M and Philippou S: Proliferative activity, p53 accumulation and neoangiogenesis in pulmonary carcinosarcomas and pulmonary blastomas. Gen Diagn Pathol 143: 265-270, 1998.

22. Mentzel T, Brown LF, Dvorak HF, et al: The association between tumour progression and vascularity in myxofibrosarcoma and myxoid/round cell liposarcoma. Virchows Arch 438: 13-22, 2001.

23. Konerding MA, Fait E and Gaumann A: 3D microvascular architecture of pre-cancerous lesions and invasive carcinomas of the colon. Br J Cancer 84: 1354-1362, 2001.

24. Vermeulen PB, Gasparini G, Fox SB, et al: Second international consensus on the methodology and criteria of evaluation of angiogenesis quantification in solid human tumours. Eur $\mathbf{J}$ Cancer 38: 1564-1579, 2002.

25. Gasparini G, Fanelli M, Boracchi P, et al: Behaviour of metastasis in relation to vascular index in patients with node-positive breast cancer treated with adjuvant tamoxifen. Clin Exp Metastasis 18: $15-20,2000$

26. Hlatky L, Hahnfeldt P and Folkman J: Clinical application of antiangiogenic therapy: microvessel density, what it does and doesn't tell us. J Natl Cancer Inst 94: 883-893, 2002. 
27. Chou CY, Huang SC, Tsai YC, Hsu KF and Huang KE: Uterine leiomyosarcoma has deregulated cell proliferation, but not increased microvessel density compared with uterine leiomyoma. Gynecol Oncol 65: 225-231, 1997.

28. Emoto M, Iwasaki H, Ishiguro $M$, et al: Angiogenesis in carcinosarcomas of the uterus: differences in the microvessel density and expression of vascular endothelial growth factor between the epithelial and mesenchymal elements. Hum Pathol 30: 1232-1241, 1999.

29. Turner KJ, Moore JW, Jones A, et al: Expression of hypoxiainducible factors in human renal cancer: relationship to angiogenesis and to the von Hippel-Lindau gene mutation. Cancer Res 62: 2957-2961, 2002.

30. Zagzag D, Amirnovin R, Greco MA, et al: Vascular apoptosis and involution in gliomas precede neovascularization: a novel concept for glioma growth and angiogenesis. Lab Invest 80 : 837-849, 2000

31. Yancopoulos GD, Davis S, Gale NW, et al: Vascular-specific growth factors and blood vessel formation. Nature 407: 242-248, 2000.

32. Gerber HP, Condorelli F, Park J and Ferrara N: Differential transcriptional regulation of the two vascular endothelial growth factor receptor genes. Flt-1, but not Flk-1/KDR, is up-regulated by hypoxia. J Biol Chem 272: 23659-23667, 1997.
33. Nomura M, Yamagishi S, Harada S, et al: Possible participation of autocrine and paracrine vascular endothelial growth factors in hypoxia-induced proliferation of endothelial cells and pericytes. J Biol Chem 270: 28316-28324, 1995.

34. Kremer C, Breier G, Risau W and Plate KH: Up-regulation of flk-1/vascular endothelial growth factor receptor 2 by its ligand in a cerebral slice culture system. Cancer Res 57: 3852-3859, 1997.

35. Clauss M, Weich H, Breier G, et al: The vascular endothelial growth factor receptor Flt-1 mediates biological activities. Implications for a functional role of placenta growth factor in monocyte activation and chemotaxis. J Biol Chem 271: 17629-17634, 1996

36. Dias S, Hattori K, Zhu Z, et al: Autocrine stimulation of VEGFR-2 activates human leukemic cell growth and migration. J Clin Invest 106: 511-521, 2000.

37. Dias S, Hattori K, Heissig B, et al: Inhibition of both paracrine and autocrine VEGF/VEGFR-2 signaling pathways is essential to induce long-term remission of xenotransplanted human leukemias. Proc Natl Acad Sci USA 98: 10857-10862, 2001. 